\title{
Comment on Conway
}

\author{
ERIK JONES
}

Put briefly, the phenomenon that historians need to address is the uniformity and stability of western Europe in the period I948-73.

Political scientists and historians use many of the same tools to address much the same questions. However, they often come to different conclusions. Perhaps it is a question of perspective. Historians may take a longer view or have a greater appreciation for detail. Political scientists may concentrate on smaller time periods while looking for larger patterns. Whatever the explanation, it is hard for me as a political scientist to accept the assertion that politics in western Europe was uniform or stable during the period I948-73. It is also hard to view I948 to I973 as a single period in the political development of western Europe. The onset of the Cold War and the first oil price shock are important historical landmarks to be sure. However, they feature in different political contexts. ${ }^{1}$

Of course none of this is to say that 'The Rise and Fall of Europe's Democratic Age, I945-I973' is a poor essay in historiography. On the contrary, it is well written, synthetic, provocative. Although I disagree with its opening thesis, I should admit that I never thought about it as a question beforehand. The political science literature has developed differently. As a result, the questions I have confronted have been different as well. In that literature, the dividing line lies in the late I950s and early I960s. The politics of the I950s was fraught with risks emanating both from the Cold War and from the process of rapid - but unequal - economic development. By contrast the politics of the late I960s and afterward had to contend with limitless aspirations and yet increasingly obvious limits to growth and to security. Finally, the diversity of the I950s represents the benchmark against which we measure convergence in an age of globalisation.

The end of the essay is easier to accept than the beginning. The concluding paragraph defends the notion that 'twentieth-century European politics was a struggle between contesting models of democracy'. The history of democracy 'is not one of progress but of discontinuous paradigms'. I would only add that this is true within west European countries as well as between them. My comments are divided into four sections: the first examines the time period, the second stability and the third uniformity; the fourth section concludes.

1 To be fair, Conway concedes this point in suggesting that 'The end is, however, distinctly less obvious.' My goal here is to establish a contrast with the assertion that 'much of that which we think happened in the I960s in fact occurred in the I970s'. From a political science perspective, it would be more accurate to suggest that most of what we witnessed in the I970s should be explained with reference to developments manifest in the early i 960 . 


\section{Dividing lines}

The western Europe that emerged at the end of the Second World War was very different from that which entered into the I970s. The turning point lies somewhere within the boundaries marked by Kruschev's secret speech and the Second Vatican Council, by Suez and Algeria, by Sputnik and the Cuban missile crisis, by the Hungarian uprising and the Berlin Wall, and by the Messina Declaration and the Elysée Accords. On one side of this pivot western Europe was openly dependent on the United States for its security, west European politics continued to revolve around ideologically informed class conflict and western Europe's economies were developing along diverse institutional trajectories. On the other side, western Europe had a more sceptical view of US security commitments, it was less ideologically motivated (although still class conscious) and it was fully engaged in an institutional reconciliation of national economic differences.

The I973 oil price shock was just one of the symptoms of this sea change in west European politics. This new western Europe did not cause the oil price shock. Nevertheless, the same factors that lay behind the transformation of western Europe did make it possible. Without decolonisation, the Organisation of the Petroleum Exporting Countries (OPEC) would not have been created in I960. Without intercontinental ballistic missiles, OPEC's control over the world's oil supply would not have been tolerated by the United States (consider the fate of Mohammad Mossadeq, the Irananian prime minister). And without divisions between the United States and Europe - particularly with regard to the Middle East - OPEC's efforts to manipulate oil prices may have been less effective (or at least that is what Henry Kissinger argued at the time, as the then US Secretary of State).

Evidence of the developments at work is not only international. National politics changed as well. In general terms, political scientists refer to this as 'the end of ideology' and 'the transformation of the western European party systems'. ${ }^{2}$ The argument is that both elites and followers began to rely less on ideology as a glue to bind them together. Ideas remained important tools for political mobilisation. But politicians and voters had more flexibility to choose between competing ideas, to mix and match depending upon their own particular interests, and to fashion political programmes without reference to canonical beliefs. By implication, the political marketplace became more fluid and political parties more competitive. Traditional cleavage structures such as centre-periphery or labour-capital remained important,

\footnotetext{
2 'The end of ideology' is a recurrent theme in the political science literature of the period. Seymour Martin Lipset also chose it as the title for his personal postscript to Political Man, although he admitted to having acquired the phrase from a previous article by Edward Shils. See Seymour Martin Lipset, Political Man: The Social Bases of Politics (New York: Anchor Books, I963), 439 ff. See also Daniel Bell, The End of Ideology: On the Exhaustion of Political Ideas in the Fifties (Cambridge, MA: Harvard University Press, I960). 'The Transformation of Western European Party Systems' was the title of an essay by Otto Kirschheimer in which he posited the end of ideological parties of mass integration and the emergence of what he called 'catch-all parties'. This catch-all party thesis became a dominant research programme in the literature on party competition and voter alignment. See Otto Kirschheimer, 'The Transformation of the Western European Party Systems', in Joseph LaPalombara and Myron Weiner, eds., Political Parties and Political Development (Princeton: Princeton University Press, I966), I77-200.
} 
as did habitual voter loyalty. And yet it was already clear by the early I960s that democratic politics in western Europe had undergone a fundamental transformation. ${ }^{3}$

The evidence for this transformation is ubiquitous. It can be found in the breakdown of the French Fourth Republic and in Michel Debrés efforts to reestablish a left-right political structure through the introduction of a two-tiered ballot. It can be seen in the negotiation of the 1958 School Pact in Belgium, the relaxation of anticlericalism among the Liberals, and the emergence of the Christian Democrats as a hegemonic centrist party. It is evident in the conflict that erupted over Adenauer's succession and the decline of the CDU/CSU into opposition. It is manifest in radicalisation of manufacturing workers in Northern Italy. And it is apparent in the collapse of corporatist price-wage negotiations in the Netherlands and in the rapid dissolution of the social 'pillars' or subnational political cultures that structured Dutch consociational democracy.

Such a transformation does not occur without some motive force. That force was economic development. Wherever development took place, ideology receded into the background. Meanwhile, democratic politics became more fluid and more competitive - particularly at the centre of the political spectrum, but also on the left and the right. Herbert Marcuse referred to this as the 'convergence of opposites... where the programs of the big parties become ever more undistinguishable, even in the degree of hypocrisy and in the odor of the clichés'. ${ }^{4}$ His One-Dimensional Man described a crisis in class-based society as he perceived it in I964. It also suggested a solution: 'political radicalization would have to be accompanied by the emergence of an independent political consciousness and action among the white-collar groups - a rather unlikely development in advanced industrial society'. ${ }^{5}$

That solution was already in train. Economic development may have blunted the conflict between labour and capital, but it also engendered new tensions between a generation inured to the hardships of war and depression and a generation fortunate enough to be born in more prosperous times. The older generation was materialist in its outlook. The newer generation was post-bourgeois. This was the thesis put forward by Ronald Inglehart in his analysis of 'The Silent Revolution in Europe'. ${ }^{6}$ In this analysis, the events of 1968 were the consequence and not the cause of the dynamics at

\footnotetext{
3 The persistence of political cleavages is another major research question in the party competition and voter alignment literature. The seminal work is Seymour Martin Lipset and Stein Rokkan, 'Cleavage Structures, Party Systems, and Voter Alignments', in Seymour Martin Lipset and Stein Rokkan, eds., Party Systems and Voter Alignments: Cross-National Perspectives (New York: The Free Press, I967), I-64. Lipset and Rokkan conclude their essay by noting that changes in voter alignments in Scandinavia and Germany were already under way by the early to mid-I96os (see 54-6).

${ }^{4}$ Herbert Marcuse, One-Dimensional Man: Studies in the Ideology of Advanced Industrial Society (Boston: Beacon Press, I964), I9.

5 Ibid., 38 .

${ }^{6}$ Ronald Inglehart, 'The Silent Revolution in Europe: Intergenerational Change in Post-Industrial Societies', American Political Science Review, 65, 4 (I97I), 99I-Ior7. See also Ronald Inglehart, The Silent Revolution: Changing Values and Political Styles among Western Publics (Princeton: Princeton University Press, I977).
} 
work. The turning point came earlier. For example, when German respondents were asked which of the 'four freedoms' they considered most important, freedom from want received 35 per cent support in I954 and only I 5 per cent in I963. Freedom from fear also held a diminishing attraction, falling from i 7 to io per cent. Meanwhile, the percentage of respondents prioritising freedom of speech increased from 32 to 56 per cent. Inglehart admitted that generational change could account for only a fraction of this shift in values. The rest he attributed to the declining 'relative scarcity' of material goods in an age of increasing prosperity. Inglehart also accepted that the German data might exaggerate the overall picture, given the country's unique role in the Second World War and also its dramatic growth in the I950s. Such qualifications aside, however, the point remains that the turning point lay in the late I950s and early I960s, not later. ${ }^{7}$

\section{Elusive stability}

If the speed and magnitude of economic development gave rise to a 'post-bourgeois' politics in western Europe, it also encouraged distributive conflict. The parties in contention were not labour and capital - at least not necessarily. Rather they were the winners and losers from growth. The Belgian crisis of I950 provides a good example. The immediate catalyst for the conflict revolved around the return of King Leopold. However, the force of the explosion derived from the economic and political tensions between a rising Flemish Catholic north and a declining Walloon socialist south. ${ }^{8}$ The south battled to a draw on the royal question, winning a concession on the abdication of King Leopold in favour of his son Baudouin.

The economic issues remained to be decided. However, resolution was postponed for two reasons - the Korean War and the European Coal and Steel Community (ECSC). A war-heightened demand for coal and steel alleviated some of the market pressures on the mature industries of Wallonia, and German-financed subsidies made it possible for the Belgian state to continue with industrial supports. This was fortunate for the state as a whole. In a political environment already overburdened by ideological battles over the state financing of Catholic schools, a renewal of economic conflict between north and south could have spelled the end of unified Belgium. $^{9}$

As luck would have it, the battle over the state financing of religious education ended in 1958 , just as those international factors supporting the mature industries of Wallonia ran out. The breathing space provided by the I950s was nevertheless sufficient. The 'great strike' of I960-I took place after the secular union of socialists and liberals had already broken down, as membership of the Catholic trade unions

7 Inglehart, 'Silent Revolution in Europe,' Ioo6.

8 See Val R. Lorwin, 'Belgium: Religion, Class, and Language in National Politics', in Robert A. Dahl, ed., Political Oppositions in Western Democracies (New Haven: Yale University Press, I966), I68-9; Jaak Brepoels, Wat Zoudt Gij Zonder 't Werkvolk Zijn? (Leuven: Kritak, I988), I58-9.

9 This is an oversimplified form of the argument made by Alan Milward in his chapter 'Coal and the Belgian Nation', in his The European Rescue of the Nation-State (London: Routledge, I992), 46-I I8. 
finally outpaced that of the socialists, and as corporatist elements across organised labour gained ascendance. The government faced calls for Walloon autonomy, but it was able to defeat them. ${ }^{10}$

No sooner had that threat receded, however, than another appeared. The European Economic Community gave a tremendous boost to the Flemish economy. This in turn coincided with a rise in the aspirations of language nationalists. And it is this combination of economic divergence and linguistic nationalism that ultimately provoked the federalisation of the Belgian state. ${ }^{11}$

The Belgian case is worth dwelling on because it illustrates a number of factors at work in the political development of postwar Europe: elite competition, welfare state expansion and regional integration. The pattern starts with competition between existing political elites for control over state resources including the elaboration of welfare state institutions and occasionally bolstered by international (regional) commitments. Over time, however, the focus for competition shifts as existing elites become institutionalised, as resources begin to be stretched, as international commitments start to constrain and as new elites emerge to threaten the system.

We can witness this pattern in most west European countries. Belgium is one example. The Netherlands is another. The early architects of the Dutch welfare state, and Willem Drees in particular, were adamant that competition be restricted to those groups willing to abide by the rules of the game. ${ }^{12}$ During the I950s, this 'game' involved co-operation between political and economic elites in the development of welfare state regimes and in the management of prices and incomes. By the early I960s, however, the pattern of co-operation began to break down. Trade unions began to compete for members. Employers defected from wage moderation agreements. The major political parties began to lose their hold over the electorate. Dutch manufacturers faced ever stiffer competition within Europe. And the Dutch welfare state exploded in size. ${ }^{13}$

The point to note is that - despite what these thumbnail sketches convey Belgium and the Netherlands are paradigmatic examples of political stability. As 'consociational democracies' and 'liberal corporatists' they are meant to define how a commitment to consensus can give rise to better politics and better economics. ${ }^{14}$ France and Britain suffer from fewer obligations to theory and illustrate the pattern

${ }^{10}$ For an overview of the I960-6I crisis, see Alain Meynen, 'De Grote Werkstaking I960-I96r: Een inleidend overzicht van de ekonomische en socio-politieke achtergronden van de grote werkstaking I960-I96I', Belgische Tijdschrift voor Niewste Geschiedenis, 9, 3/4 (I978), 48 I-5I 5.

11 For the influence of European integration on regional competition in Belgium, see Paulette Kurzer, 'Decline or Preservation of State Capacity? Political and Economic Integration Revisited', Journal of Common Market Studies, 35, I (I997), 37-40.

12 See, for example, Kees van Doorn et al., De Beheerste Vakbeweging: Het NVV tussen loonpolitiek en loonstrijd (Amsterdam: Van Gennep, I976), 40-I.

13 Jan L. Van Zanden, The Economic History of the Netherlands: A Small Open Economy in the 'Long' Twentieth Century (London: Routledge, I998), 64-7.

14 The classic work on consociational democracy is Arend Lijphart, 'Consociational Democracy', World Politics, 2I, 2 (1969), 207-25. For liberal corporatism see Peter Katzenstein, Small States in World Markets: Industrial Policy in Europe (Ithaca, NY: Cornell University Press, I985). Both works have spawned whole literatures on the merits of a consensual political economy. 
even more readily. So does Italy. And so does West Germany. The pattern extends to central and eastern Europe as well. It lies behind the Hungarian uprising. And it is at work in the Prague Spring. What differs in these non-western cases is the constraint of international commitment. Once that constraint is lifted, the appearance of stability evaporates. ${ }^{15}$

In each case, the threat of instability exists throughout. It emanates from the process of economic development. And it justifies the creation of the welfare state, its elaboration and its perpetuation - both politically and institutionally. ${ }^{16}$ What is more, the pattern of development introduces elements of instability of its own. Parties that fail to represent ever increasing numbers of the electorate begin to draw support directly from the state. ${ }^{17}$ Welfare state institutions give rise to defensive constituencies as well as to market rigidities. ${ }^{18}$ And burgeoning state finances change incentives, absorb credit, and - where bond financed - draw down on future income. Stability is not only hard to grasp, its pursuit is self-defeating.

\section{Unity in diversity}

The pattern of development across western Europe was much the same. However, the west European states themselves were not. The distinction derives from institutions and from the influence of institutional factors on the 'rational' calculation of selfinterest. Different groups have to face different problems which they address with different institutional solutions. These institutions in turn not only influence group formation, they also influence the nature of future problems and the merits of future solutions. In the modern jargon of political science, institutional development is path-dependent even in the presence of purely rational actors.

Karl Polanyi first made this claim about the inherent diversity of the welfare state at the end of his study of the Great Transformation. Polanyi's argument was that the Great Depression and the Second World War had finally brought to an end any pretension about the organic character of international free markets and international economic convergence. He asserted that only state institutions are 'natural' - if by natural we mean unplanned. And state institutions are themselves contextually determined. By implication it would be unrealistic to assume that the welfare states of western Europe either had the same origins or developed along the same trajectories. They are different and determinedly so. ${ }^{19}$

Polanyi was not alone in making this claim. Gunnar Myrdal used a similar argument to explain early setbacks in European integration. And John Gerard Ruggie used

\footnotetext{
15 Consider, for example, Alexander Eckstein, 'Economic Development and Political Change in Communist Systems', World Politics, 22, 4 (I970), 475-95.

16 David R. Cameron, 'The Expansion of the Public Economy: A Comparative Analysis', American Political Science Review, 72, 4 (I978), I243-6I.

17 Richard S. Katz and Peter Mair, 'Changing Models of Party Organizations and Party Democracy: The Emergence of the Cartel Party', Party Politics, I, I (I995), 5-28.

18 Pierson, Paul, 'The New Politics of the Welfare State', World Politics, 48, 2 (I996), I43-79.

19 Karl Polanyi, The Great Transformation: The Political and Economic Origins of Our Time (Boston: Beacon Press, I944, I957).
} 
Polanyi's analysis to explain the structure of the international system set up by the United States at the end of the Second World War. For Myrdal and for Ruggie, the diversity of west European welfare states set the limits to international integration. Hence diversity was not only the hallmark of western Europe, but of the West as well. ${ }^{20}$

The success of European integration lay in the reconciliation of this diversity within a common set of institutions. Those early theorists of integration who expected a homogeneous Europe to form were disappointed. ${ }^{21}$ By contrast, those theorists who remained committed to the vitality of the nation-state were not. More obstinate than obsolete, the state in western Europe should be celebrated more for its resilience than for its stability during the I950s and I960s. ${ }^{22}$

\section{Lessons from the past}

The countries of western Europe were often unstable, and they were caught in the throes of a profound political and economic transformation. Yet somehow they managed not only to survive but also to establish a framework within which they could continue to survive. The crises of the I970s and early I980s put that framework and those nation-states - to the test. And they passed. The question to consider is whether the formula for accommodation remains resilient. Europe's recent history is a tale of competing democratic forms. It is not a story of progress and there is no teleological endpoint. Even the most ardent advocates of European integration are cautious about imposing any one model of democracy across the continent. Rather it is a more cautious account of the successful (and perpetual) management of political conflict.

The danger lies in underestimating the potential for violence in any competition between democracies - whether such competition exists between different countries or between different groups in the same country. If we accept that all democratic paradigms are discontinuous, then we must be wary of safeguarding the bridge between any one manifestation and its successor. This - it seems to me - is the real lesson of the early postwar period. It is also the real virtue of European integration and of the welfare state. Careful study of the rise and fall of Europe's democratic age helps to remind us of this fact. Linking that study to more contemporary analysis of politics may help to ensure that we do not soon forget.

\footnotetext{
20 See Gunnar Myrdal, An International Economy: Problems and Prospects (New York: Harper \& Brothers, I956); John Gerard Ruggie, 'International Regimes, Transactions, and Change: Embedded Liberalism in the Postwar Economic Order', International Organization, 36, 2 (I982), 379-4I 5.

21 See, for example, Donald J. Puchala, 'Domestic Politics and Regional Harmonization in the European Communities', World Politics, 27, 4 (I975), 496-520.

22 The allusion here is to the famous essay by Stanley Hoffmann. See Stanley Hoffmann, ed., Conditions of World Order (Boston: Houghton Mifflin, I968), I Io-63. See also David P. Calleo, Europe's Future: The Grand Alternatives (London: Hodder \& Stoughton, I965).
} 